THE parlous financial position of Britain's Medical Research Council (MRC) is obliging the council to reconsider the future of any research to which it is not "irrevocably committed". The futures of three research units supported by the council are now described as "under review" following critical reports by visiting parties that, in some cases at least, recommended the council to consider closure.

The council said that a decision had been taken "in principle" to close its unit of neurochemical pharmacology at Cambridge (see Nature 7 June, p.486). But, as if to advertise that British medical research is not completely moribund, the council has also announced a new research unit to undertake laboratory studies of tuberculosis.

Surprisingly, the location of the new unit has not yet been finally decided, although the probable choice will be the Royal Postgraduate Medical School at Hammersmith, London. The new unit will replace two existing units in London, one at Hammersmith and one at the Brompton Hospital, Fulham, which are to be closed when their directors retire shortly.

The formation of the new unit signals a shift away from the study of the effects of tuberculosis on communities and of chemotherapy towards the use of new techniques, including recombinant DNA technology and monoclonal antibodies. The director is to be Dr Juraj Ivanyi, now head of experimental immunobiology at

Wellcome Research Laboratories.

The three units whose future is uncertain are the Biostatistics Unit at Cambridge, the Pneumoconiosis Unit at Llandough Hospital in Penarth, South Wales, and the Mineral Metabolism Unit based in Leeds. A report by a regular visiting group to the Pneumoconiosis Unit has recommended closure, and the matter is to be considered shortly by MRC's Physiological Systems and Disorders Board. There has been a cloud over the future of the unit for some time, but the recommendation to close it was still a surprise to staff, who say they will be able to enter pleas for continuation when the board's recommendations, together with the unit's responses, are formally considered by MRC. The unit has no director in post at present, thus facilitating any closure decision.

The Mineral Metabolism Unit is also without a director, but its acting director, Dr M. Peacock, seems unwilling to accept that closure is one option to be considered by the disorders board. The unit's work on osteoporosis and adrenal stone disease is in line with recommendations of an international review of calcium in metabolism, and Dr Peacock is confident that MRC will find "no scientific grounds" to close the unit, although there have been some recent staff reductions. Much the same applies to the Biostatistics Unit, where interviews for a replacement director for Dr I. Sutherland have been called off at short notice.

Tim Beardsley

\title{
No sale yet for UK chip-maker Inmos
}

THE British Government is apparently stil] undecided about how it should introduce private capital into Inmos, the statebacked semiconductor manufacturer. The company, which started to trade profitably in the final quarter of 1983 , has been provided with government capital of $\mathfrak{\ell 6 5}$ million and loans and guarantees worth $£ 40$ million, and the Secretary of State for Trade and Industry, Mr Norman Tebbit, is keen to reduce the strain on the public sector borrowing requirement.

Earlier this month, Mr Kenneth Baker, Minister for Information Technology, said in the House of Commons that the government had vetoed a private share placing organized by the company that would have raised $\mathbf{2} 30$ million, on the grounds that the terms were not sufficiently attractive. $\mathrm{Mr}$ Baker's answers to supplementary questions made it clear that the government is anxious that Inmos technology should continue to be accessible to British industry and that there should be a commitment to continued development and expansion of Inmos's activities in Britain.

More recently, Thorn EMI has made public its offer of $\mathbf{£ 1 0}$ million for a share of the company, an offer which Inmos's chairman Sir Malcolm Wilcox described as "very interesting". But the matter is still under consideration by the Department of Trade and Industry, which oversees the nominal holder of public shares in Inmos, the British Technology Group.

The US communications group AT\&T (American Telephone and Telegraph) is also now bidding again for Inmos. An approach by AT\&T was rejected by the board of Inmos in February, but negotiations are now under way directly with the government. AT\&T has, as a nod towards the principle of keeping some of Inmos's activity based in Britain, agreed that some of its research and development activity might be carried out by ICL, the British computer company. AT\&T is understood to have made an offer of $£ 45$ million for the whole company, a figure regarded as derisory by Inmos management.

Inmos is now making a monthly profit of around $£ 1$ million and has great hopes for the future with its revolutionary “transputer" chip.
Neural tube defects British vitamin trial starts slowly

THE controversial British clinical trials of vitamin supplements in the prevention of spina bifida and other neural tube defects has begun, but on a much smaller scale than originally intended. A progress report issued last week said that so far the Medical Research Council (MRC) has recruited 132 women to the trial, still far short of the 2,000 target.

Even so, MRC says it is reasonably confident that recruitment will accelerate as new centres join the study. So far, physicians at a total of 16 medical centres in the United Kingdom and 12 overseas have agreed to take part, all with the approval of their local ethical committees.

The decision to conduct control trials with vitamin supplements was taken in December 1982, partly because of research by Professor R.W. Smithells at the University of Leeds which seemed to show that neural tube defects might be prevented by vitamin and particularly folic acid supplements before and immediately after conception. To separate the effects of folic acid from those of other vitamins, MRC advocated clinically controlled trials with randomly selected patients.

The trial has been controversial because the four groups of women to which volunteers are assigned at random includes one to whom only a placebo will be administered. During the past two years there have been complaints that the use of a placebo group is unethical in the face of prima facie evidence that vitamin supplements will prevent neural tube defects, and that it may even be a breach of the revised Helsinki code of 1975 on the use of human subjects in research. There is also some concern that the daily dose of folic acid being administered to one of the four groups in the MRC study is, at 4 milligrams per day, ten times that used in earlier work.

Recruits to the study, who must first declare themselves to their personal physicians, include only women who have already given birth to a child with spina bifida or encephaly and among whom the chance of a recurring defect is, at 3 per cent, comparatively high. MRC insists that the anxieties of protesters such as the National Childbirth Trust at the ethical basis of the trial are answered by its information leaflet for participants, which says that the consent of the woman's husband will normally be required and that women's medical care will not be diminished if they do not volunteer.

So far, 18 of the 132 recruits to the study have become pregnant (and one has produced a normal child). Whether the target number of 2,000 recruits will be found within five years is at this stage by no means certain.

Judith Abel 